\title{
Class Conflict in Siraiki Waseeb Before Islam
}

\author{
${ }^{a}$ Muhammad Akhtar, ${ }^{\text {b }}$ Muhammad Mumtaz Khan \\ ${ }^{\text {a }}$ Ph.D Scholar, Lecturer in Siraiki, Govt. Associate College Civil Lines, Multan, Pakistan \\ ${ }^{\mathrm{b}}$ Assistant Professor, Department of Siraiki, The Islamia University, Bahawalpur, Pakistan \\ Email: mumtaz.khan@iub.edu.pk
}

\begin{tabular}{|c|c|}
\hline ARTICLE DETAILS & ABSTRACT \\
\hline History: & \multirow{9}{*}{$\begin{array}{l}\text { The history of class conflict in Siraiki Waseeb is as old as the Indus } \\
\text { Valley Civilization. The history of Indus Valley is interpreted as a } \\
\text { conflict of invading nations. The Siraiki Waseeb can be called the center } \\
\text { of the valley. The class system of the Siraiki Waseeb is influenced by the } \\
\text { arrival of various nations. The ancient Australoid tribes, the Dravidians } \\
\text { and the Aryans had a profound effect on the civilization here. This } \\
\text { division is wrapped not only in economic but also in the social cloak of } \\
\text { religion. Along with the division of rich and poor, the system of division } \\
\text { between pure and impure, masters and slaves, feudal, landlord and } \\
\text { 'kammi' has sustained itself parallel to the caste system. The roots of } \\
\text { the class system are still embedded in the Waseeb. These class factors } \\
\text { have been analyzed in the article under discussion. }\end{array}$} \\
\hline Accepted o6 April 2021 & \\
\hline Available Online June 2021 & \\
\hline Keywords: & \\
\hline Class Conflict, Siraiki Waseeb, & \\
\hline $\begin{array}{l}\text { Kammi And Shudra, Barhamans, } \\
\text { Upper Class, Lower Class }\end{array}$ & \\
\hline JEL Classification: & \\
\hline$D 74$ & \\
\hline & \\
\hline DOI: $10.47067 /$ real.v4i2.156 & $\begin{array}{l}\text { (C) } 2021 \text { The authors. Published by SPCRD Global Publishing. This is an } \\
\text { open access article under the Creative Commons Attribution- } \\
\text { NonCommercial } 4.0\end{array}$ \\
\hline
\end{tabular}

Corresponding author's email address: mumtaz.khan@iub.edu.pk

\section{Introduction}

Different ideologies are embodied in the leaven of Seraiki Waseeb. In this sphere there are all the beliefs, customs, religions and philosophies which Waseeb tried to adopt in different stages. Whether these were the ancient Australoid tribes, the Dravidians or the Aryans who came after them, the life style and beliefs of these nations have had a profound effect on the civilization of the Siraiki Waseeb. Greek, Iranian, Afghans, White Huns and the rulers of the Arab nations also exerted their influence. In terms of religious beliefs, Hinduism, Buddhism, Jainism and Islam influenced Waseeb with their thoughts. Administratively, Siraiki Waseeb can be said to be the center of ancient Indus Valley Civilization which has been expanding and limiting its borders in different periods. Siraiki Waseeb covers a vast area of Indus Valley. For this reason, as well, Siraiki Waseeb is always mentioned in the history and geography of Indus Valley Civilization. Ijaz ul Haq Quddosi writes about the geographical boundaries of Siraiki Waseeb and Indus Valley Civilization of ancient time:

[Translation] "The country, which was called Sindh during the reign of Raja Dahar before the advent of Islam, runs west to Makran, south to the Arabian Sea and Gujarat, east to the middle of present Malwa and Rajputana and in north passing through Multan and was spread to the Southern Punjab. Arab historians called this area Sindh. Moreover, this 
country is so ancient that it cannot even be said about it since when it has existed and what changes has occurred in its name. History only tells that when the Aryans came to this country thousands of years ago today, they named it 'Sindhu', because they used to call the river Indus in their language." (Quddosi, 2004)

The Indus Valley refers to the land of the Indus river and its tributaries, which extended as far as Makran, Kashmir and Kabul. The central region of Indus Valley was Siraiki Waseeb which is geographically the North-Western area of sub-continent. Taking into account the provinces of the government of Rai Sehris, Ijaz-ul-Haq Qudusi writes about the geographical boundaries of Multan province:

[Translation] "This province included areas from Sikkim, Berhampur, Karwar, Ashhar and Takiya to the areas up to the borders of Kashmir. The border of this province was joined with Kashmir." (Quddosi, 2004)

The history of Seraiki Waseeb is thousands of years old. The fertility of its land has always attracted outsiders. The Australoid tribes are the first of the nations which arrived here. These tribes included Kol, Bheel, Santhal, Munda and Kolari etc. Before the Dravidians, there was a concept of upper and lower class in these tribes. Dr. Tara Chand writes:

[Translation] "Before the Aryans came to Hindustan, the people who lived here had many sects. The first sect was the savage Abyssinians, who had a very low status in society and who were forced to take up low-level occupations. They were the descendants of the ancient inhabitants. The Kol (Australoids) and civilized Dravidian people were of higher status." (Chand, 1968)

After these tribes, Dravidians entered the valley. Dravidians were more civilized than these tribes. They subjugated these tribes. The concept of pure and impure existed before these tribes. Dravidians adopted agriculture. The culture of slavery started with agriculture. The division of pure and impure then then appeared as upper and lower classes. Ancient tribes emerged as lower class while Dravidians as civilized ones. After the Dravidians, the Aryans entered the valley. They either killed the Dravidians by attacking them or pushed them towards the forests or enslaved them. Dr. Nasrullah Khan writes:

[Translation] "The other people of the Indus Valley who have had a profound effect on the civilization and society here were the Aryans.” (Nasir, 2007)

The landscape changed after the arrival of Aryans in the Indus Valley. The locals were either made slaves or were forced to emigrate. These locals were already divided between the pure and impure classes. Muhammad Omar writes:

[Translation] "The early Aryan immigrants who migrated to Hindustan were nomadic herdsmen but were free from the shackles of social groups and class divisions as the study of the Rig Veda sheds light on the existence of three different groups. Whereas, the indigenous people, who were divided into two groups, pure and impure, emerged as lower castes.” (Omer, 1975) 
Whether it is a reunion between two nations or a war, there is a sense of superiority in minds. Aryans who entered the valley as conquerors had the feeling that they were superior. They used to call the enslaved and fleeing locals as Das, Shodar and Desu. Umrao Bahadur writes:

[Translation] "Apart from Arya Jati, some people of Anarya Jati were also settled in India at that time and they were called Desu or Das by these Arya Jati. There were frequent Aryan battles with these people." (Bahadur, 1938)

The Aryan groups kept coming regularly. There were wars among them. As a result of these wars, these groups were divided into classes. However, the ancient inhabitants of the valley were called Nech, Rakshas, Shoodar and Dasu. Shamim Arif Qureshi writes:

[Translation] "In fact, in the Indus Valley, the words Nech, Kaan, Kojha, Kehl and Niggards were used by the Aryans for the black Dravidians and local people.” (Qureshi, 2006)

The meaning of the word "Arya” also highlights the class division. D. D. Kosambi explains the meaning of the word Arya:

[Translation] "The word "Arya" in Sanskrit and in most Indian dialects from this language onwards has the meaning of "born free" or "noble" or a member of the three higher castes. The word, like many other words, has changed its meaning over the centuries.” (Kosambi, 2012)

When the Aryans settled in the valley, they created their own religious hymns. These hymns were written on the banks of rivers in Siraiki Waseeb. There are references of the rivers of Siraiki Waseeb with much respect and honor. River Sarasvati/Hakra, Sutlej, Beas and Sindh are mentioned in these hymns a number of times. These Vedas were written in Sanskrit. The language of these Vedas was considered superior by the Brahmins. This Vedic language could only be spoken by the upper class. In the process, the religious class came to the fore as superior class. This position of the Brahmins has been described by Syed Ali Shah Multani as follows:

[Translation] "If we look at the Brahmins, according to their statement, Sanskrit is a heavenly language which only the gods spoke. Later this dialect was gradually learned by the Brahmins and is now preserved in the holy books of the Hindus." (Multani, 2019)

In the later times, the Aryans introduced a strict caste system. The Brahmins tightened the social rules to keep their status high. Strict punishments were given to psychologically weaken the lower classes. The purpose of the life of these classes was to serve their upper classes. Gustauli Ban has listed some of the Manushastras:

[Translation] "Serving a Brahmin is a very commendable thing for Shudra and he can get no good from anything else." (Chapter $X, 123$ )

[Translation] "If Shudra raises his hand against the other, his hand will be cut off. If he kicks in anger, his leg should be amputated.” (Chapter VIII, 280).” (Gustauliban)

The Aryans abandoned nomadism and took up agriculture. Brahmins among them became the contractors of religion. Kashtari turned their attention to other administrative matters and farming. 
They cleared and farmed the land as much as possible. In this regard Muhammad Omer writes:

[Translation] "Gradually, they abandoned herding and looked for other sources for their income. Therefore, they started farming. Their relationship with the earth was established. Permanent settlement led to the evolution of the agrarian society." (Omer, 1975)

The agrarian society further clarified the class conflict. Manpower for farming made the need for slavery and the lower classes more pronounced. This process of farming gave rise to the concept of land ownership and monarchy. Farming gave birth to chiefs and feudal lords. Maulvi Abdul Karim writes in "Tawareekh-e-Hind":

[Translation] "In the beginning, the special division of the Aryan nation was done for the sake of the administration of the state and for the goodwill. Otherwise, they were all united as one. However, as time went on, the number of nobles and wealth increased." (Karim)

Four social classes appeared in that time period which were; Brahman, Kashtari, Vaish and Shudra. Brahmins became religious leaders, Kashtari held administration and others state affairs, Vesh worked for the agriculture while the Shudras for the service of the upper classes. Gustauli Ban writes:

[Translation] "The first division between these castes was between the Brahmins and the Kashtriyas. Gradually, the Brahmins who were considered to be in between man and god rose in the ranks and they asserted their greatness. The distinction between the fighters and the peasants was made after that and it was mostly due to the group of fighters." (Gustauliban)

This division of the Vedic age was different from any other class society in the world because the lower class was not only economically weak but its life was only meant for slavery. It had no rights and the social condition of this class was worse than that of animals. Syed Muhammad Taqi writes:

[Translation] "While dividing the humans into four classes, the sub-continent deprived the lower classes of not only the basic human rights but also the rights they had as a living being. To consider even the shadow of a poor or lower class as impure or "nijs" and the poor being compelled to move 200 yards away from the upper class person so the rich may not become impure, was such a mindset that did not exist in any other class society in the world. In fact, the old Hindu civilization has added an element to the class conflict of societies. This element is the concept of impurity." (Taqi, 1968)

The fifth and sixth centuries BC are important because in those centuries extraordinary personalities were born in the world. Great figures such as Pythagoras in Greece, Confucius in China, Zoroaster in Iran, and Gautama and Mahabir in India illuminated these centuries by preaching their religions. They not only influenced their own societies but the impact of their teachings also reached to other countries. Among these great personalities, Gautama Buddha had a distinction. His religion gained global appreciation. Gautama Buddha was born in the middle of 600 BC. Gautama Buddha was kind and compassionate by nature. His teachings were based on compassion and morality. Buddhism discouraged castes and classes. Munshi AhmadudDin writes in his book "Sawaneh Umari Mahatama Budh ": 
[Translation] "In due course of time, the religion of Buddha spread to India, Ceylon, Brahma, China, Japan, Tibet, Manchuria, Korea, Anam, Hisyam, and other countries. Most of the development of this religion was due to its simplicity of the issues, the avoidance of caste bias, the emancipation of women, and the sending of missions to different countries." (AhmedudDin, 1903)

Like Buddha, Mahabir founded Jainism. Mahabir put forward four principles. These principles were: don't take anyone's life, don't take any other's property, don't keep any of your own property and be honest. If we talk about the influence of Jainism and Buddhism in the Siraiki Waseeb, then the influence of Buddhism has remained in the Seraiki Waseeb for a long time.

[Translation] "The dominance of Buddhism in Siraiki and Sindh region lasted for a longer period as compared to India and Punjab." (Gadi, 2004)

Ashoka (406 BC), the grandson of Chandra Gupta Morya, converted to Buddhism and arranged for its preaching. But in his time, the condition of Shudra peasants was worse. Dr. Ram Sharan Sharma writes:

[Translation] "In the Mauryan period, the tendency to take agricultural work from Shudra laborers reached its peak." (Sharma, 1979)

Buddhism flourished in the time of Ashoka. However, only a century later it began to decline because the difference between Buddhism and Brahmanism was of morality. Gustauliban writes about this philosophy and difference:

[Translation] "As philosophy became more entrenched in Buddhism and religion ceased to exist and since no nation in the entire world depends on religion more than Hindus, Brahmanism regained the chance and eventually dominated. They brought the followers of Buddhism into their fold. Therefore, Buddhism which is currently followed by 50 million people is only a form of Brahman religion." (Gustauliban)

The regular movement of the Brahmins against Buddhism drove them out of India. The Brahmins persecuted the Buddhists. T.W. Rhys Davids points to these atrocities:

[Translation] "The statements of the Brahmins attribute the success of the last stages of the revolutionary movement to the most severe atrocities that were inflicted on the Buddhists at the behest of the famous Brahmin leader Kumarla Bhutta in the first half of the eighth century. Leading European researchers Wilson and Cole Brook second this opinion.” (Davids, 1992)

This war of the upper class in society was not only religious but was also intended to maintain intellectual dominance over the lower class. The Brahmins sanctified it as religion and divinity and put it away forever. Now the lower classes were wrapped in the beautiful blanket of religion which was based on anti-human thinking. Buddhism challenged this thinking, but it was deported.

[Translation] "Buddhism was a reaction against this barbaric social system, but it could not take root in India as the class-ridden Indian civilization had very deep foundations. Therefore, Buddhism itself was forced to leave Hindustan and lost its Hindustani roots in 
conflict with the system of Brahmanism.” (Taqi, 1968)

The fundamental difference in social equality that characterized the teachings of Buddhism disappeared over time. The class system remained in place. New classes emerged. Under the rule of the Gupta family, another class of government employees emerged. This class can be called the middle class. Muhammad Mujeeb has written:

[Translation] "The number of government officials was much higher than in the Maurya era, but the nature of their duties and powers is not yet known. Most of the positions were hereditary and that is why there must have been a separate class of government employees. The country's economic organization, as before, was still dependent on the communities of traders and industrialists, and the government was very mindful of them." (Mujeeb, 1999)

The White Huns, who invaded Multan after Alexander the Great, also played a role in mitigating the effects of Buddhism. White Huns were priests of the sun god. They built a large temple of the sun god in Multan. After the overthrow of their government, no major central government could be established here and Buddhism in particular declined. Muhammad Nafees Ibtisam writes of the class, religion, government, and condition of the people in this age:

[Translation] "Huns built a big temple of the sun god in Multan. Buddhist stupas were deserted. Their lives were made miserable. Buddhist were limited there. After the fall of the central rule of Huns, no big and strong government could be established here. The Hindu Raja and Maharaja continued to play the game of power here. Both religion and power began to be used to exploit the people. Class conflict spread sharply. The life of Shudras was made unbearable." (Ibtisam, 1998)

All the nations that entered the valley before the Muslims, in one way or another, exposed the perception of the classes within themselves. The oppressed classes were psychologically so much weakened that they considered oppression as destiny and the will of god. Even before the advent of Islam, the conditions in this society were such that a religion that teaches equality was to be accepted immediately.

\section{References}

AhmedudDin, M. (1903). Mahatama Budh, Sawaneh Umari. Lahore: Anarkali Kashmiri Press.

Bahadur, U. (1938). Bharat Puraan. Dehli: Dehli Press.

Chand, D. T. (1968). Ahl-e-Hind ki Mukhtasir Tareekh. Dehli: Urdu Acedemy (Regd).

Davids, T. R. (1992). The Story of the Nation (Budhmati Hind). Deccan: Dar-ul-Tabey Usmania, Hyderabad.

Gadi, U. F. (2004, May). Siraiki Culture. Sunjaan, 5th edition, p. 25.

Gustauliban. (n.d.). Tamaddun-e-Hind. Lahore: Mushtaq Book Corner, Urdu Bazar.

Ibtisam, M. N. (1998). Multan aur Suhurwardiya Silsila. Lahore: Al-Faisal Nashiran.

Karim, M. A. (n.d.). Tawareekh-e-Hind. Deccan: Syed Abdul Qadir sahib, Tajir Kutub, Chaar Minar, Haiderabad.

Kosambi, D. (2012). Qadeem Hindustan. Lahore: Book Home.

Mujeeb, M. (1999). Tareekh e Tamaddun e Hind. New Dehli: Qaumi Council baraye Farogh Urdu Zuban, Wazarat e Taraqqi Insani Wasail, Govt. of Hind. 
Multani, S. A. (2019). Multani Zuban kia hai. Rawalpindi: Awaz Publication.

Nasir, N. K. (2007). Siraiki Shayari da Irtaqa. Multan: Siraiki Adabi Board.

Omer, M. (1975). Hindustani Tehzeeb ka Musalmanon per Asar. New Dehli: Director Publications Division, Minister of Information, Govt. of India.

Quddosi, I. (2004). Tareekh-e-Sindh. In I. Quddosi, Tareekh-e-Sindh (p. 01). Lahore: Urdu Science Board.

Qureshi, S. A. (2006, August). Jadeed Siraiki Adab, Rujhanaat, Imkanaat. Daily Khabrein.

Sharma, R. C. (1979). Qadeem Hindustan mein Shoodar. New Dehli: Taraqqi Urdu Board, Indian Council of Historical Research, New Dehli.

Taqi, S. M. (1968). Hindustan Pusmanzar o Paishmanzar. Karachi: Anjuman e Taraqqi e Urdu. 